\title{
Similar herpes zoster incidence across Europe: results from a systematic literature review
}

\author{
Sybil Pinchinat ${ }^{1}$, Ana M Cebrián-Cuenca ${ }^{2}$, Hélène Bricout ${ }^{3^{*}}$ and Robert W Johnson ${ }^{4}$
}

\begin{abstract}
Background: Herpes zoster $(\mathrm{HZ})$ is caused by reactivation of the varicella-zoster virus (VZV) and mainly affects individuals aged $\geq 50$ years. The forthcoming European launch of a vaccine against $\mathrm{HZ}$ (Zostavax ${ }^{\circledR}$ ) prompts the need for a better understanding of the epidemiology of $\mathrm{HZ}$ in Europe. Therefore the aim of this systematic review was to summarize the available data on $\mathrm{HZ}$ incidence in Europe and to describe age-specific incidence.

Methods: The Medline database of the National Library of Medicine was used to conduct a comprehensive literature search of population-based studies of HZ incidence published between 1960 and 2010 carried out in the 27 member countries of the European Union, Iceland, Norway and Switzerland. The identified articles were reviewed and scored according to a reading grid including various quality criteria, and $\mathrm{HZ}$ incidence data were extracted and presented by country.

Results: The search identified 21 studies, and revealed a similar annual HZ incidence throughout Europe, varying by country from 2.0 to 4.6/1 000 person-years with no clearly observed geographic trend. Despite the fact that age groups differed from one study to another, age-specific $\mathrm{HZ}$ incidence rates seemed to hold steady during the review period, at around 1/1 000 children $<10$ years, around 2/1 000 adults aged $<40$ years, and around 1-4/1 000 adults aged 40-50 years. They then increased rapidly after age 50 years to around 7-8/1 000, up to 10/1 000 after 80 years of age. Our review confirms that in Europe $\mathrm{HZ}$ incidence increases with age, and quite drastically after 50 years of age. In all of the 21 studies included in the present review, incidence rates were higher among women than men, and this difference increased with age. This review also highlights the need to identify standardized surveillance methods to improve the comparability of data within European Union Member States and to monitor the impact of VZV immunization on the epidemiology of $\mathrm{HZ}$.

Conclusions: Available data in Europe have shortcomings which make an accurate assessment of $\mathrm{HZ}$ incidence and change over time impossible. However, data are indicative that $\mathrm{HZ}$ incidence is comparable, and increases with age in the same proportion across Europe.
\end{abstract}

Keywords: Epidemiology, Herpes zoster, Shingles, Europe, Incidence

\section{Background}

Varicella-zoster virus (VZV) is a herpes virus that infects nearly all humans and causes two distinct diseases: varicella, the primary infection which usually occurs in childhood, and herpes zoster (HZ), a result of reactivation of VZV which remains latent in the sensory ganglia following varicella. This reactivation occurs when VZVspecific cellular-mediated immunity decreases, mainly

\footnotetext{
* Correspondence: HBricout@spmsd.com

${ }^{3}$ Epidemiology Department, Sanofi Pasteur MSD, 8 rue Jonas Salk, 69007, Lyon, France

Full list of author information is available at the end of the article
}

due to age-related immunosenescence and immunosuppressive conditions.

$\mathrm{HZ}$ is characterized by a vesicular skin rash localized in the sensory region of the affected ganglia, and is often preceded, or accompanied by acute pain or itching. The individual lifetime risk of developing $\mathrm{HZ}$ is between $23.8 \%$ and $30 \%$, or approximately 1 in 4 people [1-5]. However, for individuals aged 85 and over, this risk increases to 1 in 2 people [6]. Indeed, HZ incidence increases markedly after 50 years of age, with two-thirds of $\mathrm{HZ}$ cases occurring in individuals aged 50 years or over [7]. Anyone who has had varicella is at risk of $\mathrm{HZ}$,
C Biomed Central

(C) 2013 Pinchinat et al.; licensee BioMed Central Ltd. This is an Open Access article distributed under the terms of the Creative Commons Attribution License (http://creativecommons.org/licenses/by/2.0), which permits unrestricted use, distribution, and reproduction in any medium, provided the original work is properly cited. 
and in Europe varicella affects over 90\% of children before the age of 15 years [8].

$\mathrm{HZ}$ is painful during the acute phase, but pain may persist for months or even years. Post-herpetic neuralgia, defined as chronic pain persisting after rash onset, occurs in $20 \%$ to $50 \%$ of patients, and can lead to several months of treatment and loss of quality of life $[9,10]$. After 1 year, almost $10 \%$ of patients, mainly older people, still have persistent pain [11,12].

The forthcoming European launch of a vaccine against HZ $\left(\operatorname{Zostavax}^{\circledR}\right)$ prompts the need for a better understanding of the epidemiology of $\mathrm{HZ}$ in Europe. Therefore the aim of this review was to summarize the available data on $\mathrm{HZ}$ incidence in Europe and to describe age-specific incidence, notably among individuals aged over 50 years.

\section{Methods}

\section{Literature search}

The Medline database of the National Library of Medicine was used to conduct a comprehensive literature search of population-based studies of $\mathrm{HZ}$ incidence published between 1960 and 2010. Articles had to include the MeSH term "herpes zoster" or "shingles", as well as the keyword "incidence" or "age-specific incidence". Only articles reporting on studies carried out in the 27 European Union Member States, Iceland, Norway, or Switzerland (complete list can be found at end of this paper) were considered. Publications in Dutch, English, French, German, Italian or Spanish were considered.

References lists from retrieved publications were also checked manually for any additional studies or review articles on the epidemiology of HZ, and if necessary the authors were contacted to obtain data on age-specific $\mathrm{HZ}$ incidence rates. National surveillance data, the websites of the National Institutes of Health of the United Kingdom (UK), sentinel networks and data from the World Health Organization were also consulted, especially for countries where no publications were found. However, no additional data were identified.

\section{Selection criteria}

Included articles had to have HZ incidence data available, a population-based study design and information on the quality criteria used to score the studies in this review. Any study that did not contain this information was excluded.

All studies limited to immunocompromised populations/populations with primary or acquired immunodeficiency status, patients with hematological malignancies (acute and chronic leukemia, lymphoma or other malignant neoplasm affecting the bone marrow or lymphatic system, solid tumors receiving cytotoxic chemotherapy, hematopoietic stem cell transplantation), persons with
AIDS, patients on immunosuppressive therapy (i.e., treatment with agents, such as $\mathrm{x}$-rays, corticosteroids, or cytotoxic chemicals, etc.) were excluded. A few articles were also excluded due to duplicate publication, or lack of study dates.

\section{Quality assessment and scoring of articles}

In order to provide a methodological classification of the studies, a reading grid was created specifically for this review based on set quality criteria. According to these criteria, each selected article was scored by two independent readers. The reading grid allowed for a total of 30 possible points:

1) Representativeness of the sample of patients (12 points): number of practitioners or specialists, sampling method description and validation-if any, geographic distribution, population covered.

2) Incidence calculation (12 points): estimation of the denominator used to calculate incidence, presence of confidence intervals, estimation of age- or sexspecific incidence, size of the study, diagnostic criteria of $\mathrm{HZ}$.

3) Study design (4 points):

a) Prospective inclusion of patients (considered high-quality data) suffering from $\mathrm{HZ}$ in health care facilities during a defined study period, either during an ad-hoc study or through a sentinel surveillance network.

b) Retrospective identification of HZ cases either through the review of medical files in a sample of practitioners, or through the analysis of large databases (national registries, health insurance databases, etc.). In the first case, potential issues could arise from the quality of files and missing data. Database studies are less time- and costconsuming for assessing incidence rates; however these studies are subject to bias related to the completeness of the database and inference to the general population.

4) Discussion of the study limitations and study results put in perspective with the data from the literature (2 points).

Papers with a quality score of less than 15 out of the 30 possible points were excluded from the literature review. For the selected articles, pertinent information was extracted, including study dates, setting, study population, sample size, diagnostic criteria used for HZ, overall $\mathrm{HZ}$ incidence with $95 \%$ confidence intervals (when available), and incidence data by age, and by sex (when available).

The present systematic review is following the PRISMA guidelines [13]. 


\section{Results}

The Medline search identified 1644 articles, of which 1 563 were immediately excluded based on their abstracts. A review of the reference lists of the 81 remaining articles identified 23 additional articles, making a total of 104. Of these, 77 were excluded due to the inclusion and exclusion criteria: four hospital-based studies, six costeffectiveness studies (some epidemiological data, but obtained or derived from several community-based studies), 34 general reviews, 18 studies in countries not included in this review, and 15 with no exploitable incidence data or that lacked information on the quality criteria necessary to score the publication.

The 27 remaining articles that corresponded to the inclusion criteria were scored using the reading grid. After the reading grid was applied, six of the 27 studies were further excluded as they did not meet the threshold for inclusion (i.e., 15 points) [14-19]. Therefore, 21 articles were finally included in this review (Figure 1).

The 21 reports of HZ incidence from European countries included one from Belgium, four from France, two from Germany, two from Iceland, two from Italy, three from the Netherlands, two from Spain, one from Switzerland, and four from the UK (Table 1). No relevant data were found for the other 21 countries considered in this review (Austria, Bulgaria, Cyprus, the Czech Republic, Denmark, Estonia, Finland, Greece, Hungary, Ireland,
Latvia, Lithuania, Luxembourg, Malta, Poland, Portugal, Romania, Slovenia, Slovakia, Sweden and Norway).

Table 1 shows the main features of the included studies and HZ incidence by country. Annual HZ incidence varied by country from 2.0 to 4.57 per 1000 personyears (PY). The HZ incidence rates in the studies with a score inferior to 15 were in the same range (from 3.2 and 4.14 per 1000 person-years) $[15,16]$. The overall incidence was lower in Iceland, Germany and Switzerland (around 2/1 $000 \mathrm{PY}$ ), medium in the UK, the Netherlands and France (around 3/1 000 PY), and higher in Belgium, Spain and Italy (around 4/1 000 PY) (Table 1). However, no geographic trend of overall incidence was clearly observed (Figure 2).

It was estimated that in England and Wales alone there are approximately 225000 new cases of $\mathrm{HZ}$ each year [40]. In 2009, the French sentinel network estimated that there were around 350000 cases of $\mathrm{HZ}$ across all age groups [21]. Another study performed in France reported around 182500 incident cases among immunocompetent people aged 50 years or over [23].

Using the nine most recent studies, which had the highest quality score for their country and were performed without age criteria $[20,22,26,29,31,35,36,40,41]$, we estimated an average $\mathrm{HZ}$ incidence rate of $3.4 \pm 0.2 / 1000$ for all age groups combined. If this is applied to the total European population of 512 million inhabitants [42], a

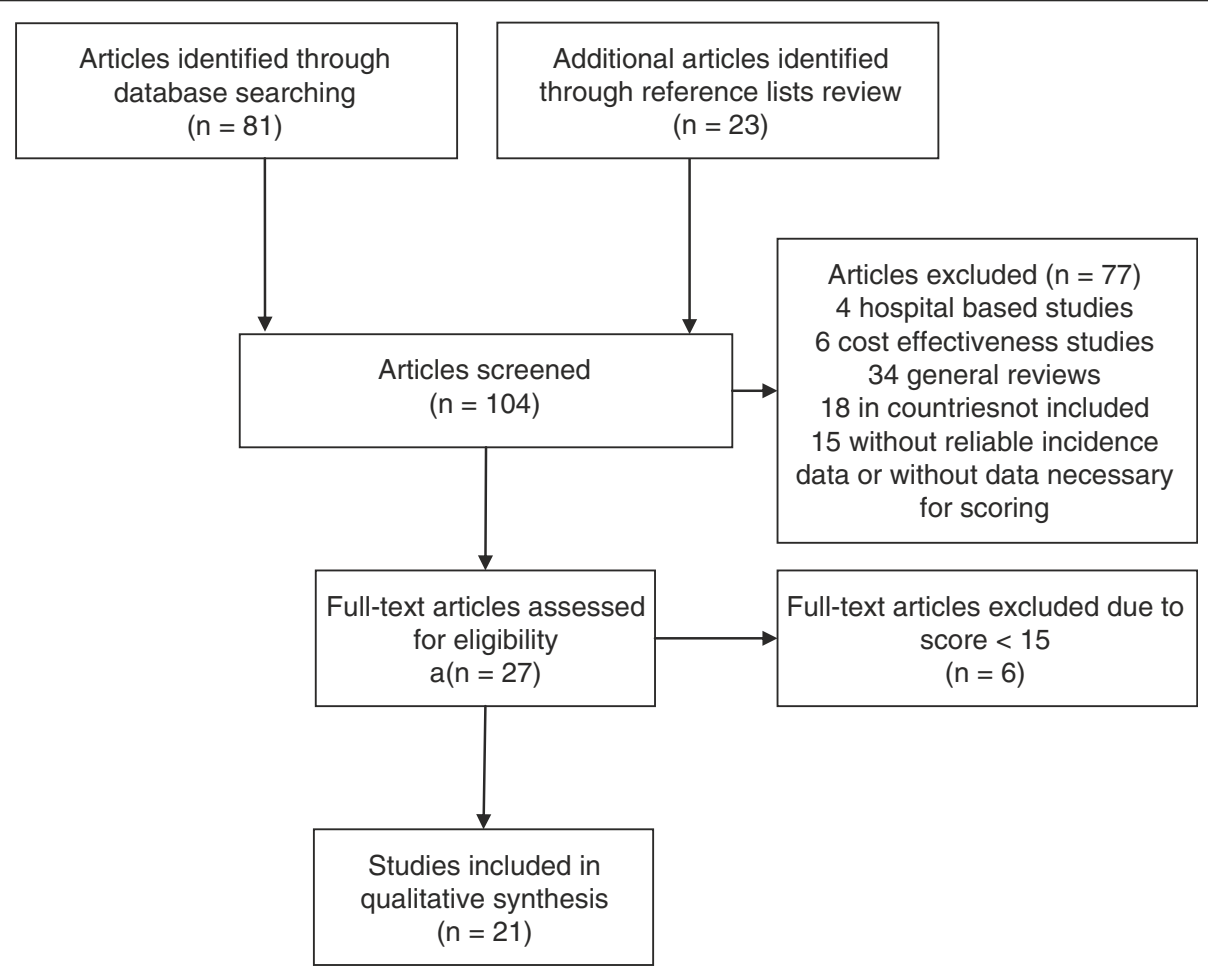

Figure 1 Flow diagram. 
Table 1 Selected details of included studies

\begin{tabular}{|c|c|c|c|c|c|c|c|c|c|c|c|}
\hline & Ref & Country & $\begin{array}{l}\text { Study } \\
\text { dates }\end{array}$ & Author & Design $^{a}$ & $\begin{array}{l}\text { Concerned } \\
\text { population }\end{array}$ & $\begin{array}{l}\text { Age } \\
\text { criteria }\end{array}$ & $\begin{array}{c}\text { Case } \\
\text { ascertainment }\end{array}$ & Diagnosis & $\begin{array}{l}\text { Cases } \\
\text { (n) }\end{array}$ & $\begin{array}{c}\text { Incidence /1 } \\
000 \text { PY }\left[95 \% \text { Cl }{ }^{b}\right.\end{array}$ \\
\hline 1 & [20] & Belgium & 1994-03 & Truyers & $A_{2}$ & Patients of 51 GPs & All & Notified by GPs & ICPC-code S70 & NR & $4.57[4.31-4.79]$ \\
\hline 2 & [21] & France & 2009 & $\begin{array}{l}\text { Sentinel network } \\
\text { (INVS) }\end{array}$ & $\mathrm{A}_{2}$ & $\begin{array}{c}454 \text { active GPs (62 } 809976 \\
\text { patients) }\end{array}$ & All & $\begin{array}{l}\text { Weekly returns of all } \\
\text { diagnoses }\end{array}$ & Individual GPs & 992 & 5.52 [5.06-5.98] \\
\hline 3 & [22] & France & $2005-08$ & Gonzales-Chiappe & $A_{2}$ & Patients of 1200 GPs & All & Notified by GPs & Individual GPs & 2375 & 3.82 [3.64-4.05] \\
\hline 4 & [23] & France & 2005 & Mick & $\mathrm{B}_{1}$ & $\begin{array}{l}\text { Patients of } 231 \mathrm{GPs}, 41 \\
\text { dermatologists, } \\
15 \text { neurologists }\end{array}$ & $\geq 50 y$ & $\begin{array}{c}\text { Postal survey - cases seen } \\
\text { in } 2005\end{array}$ & $\begin{array}{l}\text { Individuals } \\
\text { clinicians }\end{array}$ & 777 & 8.99 [8.34-9.64] \\
\hline 5 & [24] & France & 1998 & Czernichow & $\mathrm{B}_{1}$ & Patients of 744 GPs & All & $\begin{array}{l}\text { Postal survey of GPs - cases } \\
\text { seen in previous year }\end{array}$ & Individual GPs & 605 & 3.20 [3.00-3.40] \\
\hline 6 & {$[25]$} & Germany & 2004 & Schiffner-Rohe & $\mathrm{B}_{2}$ & 120399 patients & $\geq 50 y$ & $\begin{array}{l}\text { Searches in computerized } \\
\text { records }\end{array}$ & ICD-10 & 1176 & 9.80 [9.20-10.40] \\
\hline 7 & [26] & Germany & $1992-93$ & Paul & $A_{1}$ & $\begin{array}{l}\text { Population of Ansbach City } \\
\text { (about } 40000 \text { inhabitants) }\end{array}$ & All & $\begin{array}{l}\text { All cases seen by GPs, } \\
\text { dermatologists, pediatricians }\end{array}$ & $\begin{array}{l}\text { Individual } \\
\text { clinicians }\end{array}$ & 152 & 2.26 \\
\hline 8 & [27] & Iceland & 1990-95 & Helgason & $A_{1}$ & $\begin{array}{l}\text { Patients of } 62 \text { GPs (out of } \\
150 \text { GPs in Iceland) }\end{array}$ & All & Notified by GPs & Individual GPs & 462 & 2.00 [1.80-2.20] \\
\hline 9 & [28] & Iceland & 1990-95 & Petursson $^{c}$ & $A_{1}$ & Patients of 62 GPs & $<20 y$ & Notified by GPs & Individual GPs & 118 & 1.60 \\
\hline 10 & [29] & Italy & 2003-05 & EmbertiGialloreti & $\mathrm{B}_{2}$ & $\begin{array}{l}\text { Patients of } 342 \text { GPs ( } 0.8 \% \text { of } \\
\text { Italian GPs) ( } 450000 \text { patients) }\end{array}$ & $\geq 15 y$ & $\begin{array}{l}\text { Searches in computerized } \\
\text { records }\end{array}$ & ICD-9 & 5675 & $4.31[4.11-4.52]$ \\
\hline 11 & [30] & Italy & 2004 & Di Legami & $A_{1}$ & $\begin{array}{l}\text { Population of Piemonte ( } 26 \\
934 \text { patients) }\end{array}$ & $\geq 14 y$ & Notified by GPs & Individual GPs & 46 & $1.74[1.28-2.32]$ \\
\hline 12 & [31] & Netherlands & 2001 & Opstelten & $A_{1}$ & $\begin{array}{l}104 \text { GPs (about } 390000 \\
\text { patients) }\end{array}$ & All & Notified by GPs & Individual GPs & 1080 & $3.20[3.00-3.40]$ \\
\hline 13 & [32] & Netherlands & 1998-01 & de Melker & $\mathrm{B}_{1}$ & $\begin{array}{l}\text { Patients of } 43 \text { GPs (about 1\% } \\
\text { of the Dutch population) }\end{array}$ & All & Notified by GPs & Individual GPs & $N R$ & 3.25 \\
\hline 14 & [33] & Netherlands & 1994-99 & Opstelten & $\mathrm{B}_{2}$ & $\begin{array}{c}22 \text { GPs in six areas (about } 49 \\
000 \text { patients) }\end{array}$ & All & $\begin{array}{l}\text { Searches in computerized } \\
\text { records }\end{array}$ & Individual GPs & 837 & $3.40[2.90-3.90]$ \\
\hline 15 & [34] & Spain & 2007 & Cebrian-Cuenca & $\mathrm{A}_{1}$ & $\begin{array}{l}24 \text { GPs in Valencia community } \\
\text { (about } 36030 \text { patients > 14y) }\end{array}$ & $>14 y$ & Notified by GPs & Individual GPs & 146 & $4.10[3.40-4.70]$ \\
\hline 16 & [35] & Spain & 2005-06 & Garcia-Cenoz & $\mathrm{B}_{2}$ & Patients of GPs in Navarre & All & $\begin{array}{l}\text { Searches in computerized } \\
\text { records }\end{array}$ & ICD-10 & 4959 & 4.15 \\
\hline 17 & [36] & Switzerland & 1998-01 & Richard & $\mathrm{A}_{2}$ & $\begin{array}{l}\text { Patients of } 250 \text { physicians (GPS, } \\
\text { pediatricians, physicians of } \\
\text { internal medicine) }\end{array}$ & All & Notified by physicians & $\begin{array}{l}\text { Individual } \\
\text { clinicians }\end{array}$ & 2236 & 2.36 \\
\hline 18 & [37] & UK & $2000-06$ & Gauthier & $\mathrm{B}_{2}$ & $\begin{array}{l}603 \text { GPs Research Database } \\
\text { (GPRD) (3 million of patients) }\end{array}$ & $\geq 50 y$ & $\begin{array}{l}\text { Searches in computerized } \\
\text { records }\end{array}$ & $\begin{array}{l}\text { ICD-10, first } \\
\text { episode }\end{array}$ & 25002 & 5.23 [2.17-5.29] \\
\hline
\end{tabular}


Table 1 Selected details of included studies (Continued)

\begin{tabular}{|c|c|c|c|c|c|c|c|c|c|c|c|}
\hline 19 & {$[38]$} & UK & 1947-72 & Hope-Simpson & $\mathrm{B}_{1}$ & $\begin{array}{c}\text { GPs in Cirencester (about } 3700 \\
\text { patients) }\end{array}$ & All & All recorded cases & NR & 321 & 3.40 \\
\hline 20 & [39] & UK & 1994-01 & Fleming & $\mathrm{B}_{2}$ & $\begin{array}{l}\text { Up to } 91 \text { GPs (RCGP) (About } \\
200000 \text { patients) }\end{array}$ & All & Weekly returns of all diagnoses & Individual GPs & 14532 & 3.20 \\
\hline 21 & [40] & UK & 1991-00 & Brisson & $\mathrm{B}_{2}$ & $\begin{array}{l}69 \text { GPs in England \& Wales } \\
\text { ( 570000 patients) }\end{array}$ & All & $\begin{array}{l}\text { Searches in computerized } \\
\text { records }\end{array}$ & ICD-9 & 112409 & 3.73 \\
\hline
\end{tabular}

Abbreviations: $P Y$ person-years, Cl confidence interval, NR not reported, GP general practitioner, ICD-10 International Classification of Diseases, version 10, UK United Kingdom.

a Design:

A. Prospective study: $A_{1}$ ad hoc health care-based study $A_{2}$ : sentinel practice network-based study.

B. Retrospective study: $B_{1}$ :ad hoc study with review of patients' medical charts $B_{2}$ : database study.

${ }^{\mathrm{b}}$ For some studies, the confidence interval of incidence is not specified.

' The Petursson study is a sub-analysis of the Helgason study among children and adolescents aged less than 20 years. 


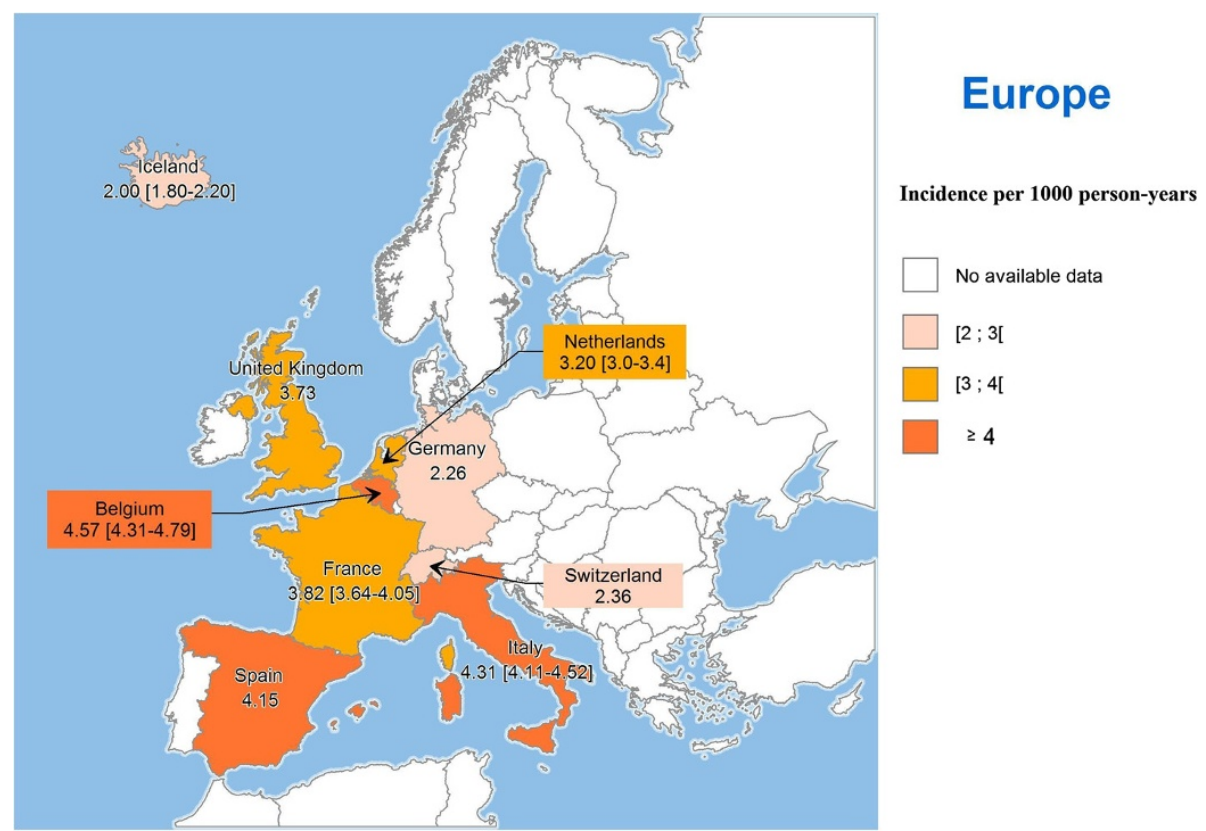

Figure 2 Overall annual herpes zoster $(\mathbf{H Z})$ incidence rates in Europe (/1 000 person-years). Notes: The confidence interval is presented when available in the original publication. In case of several publications per country, the publication with the most recent data and that reported the overall $\mathrm{HZ}$ incidence rate is depicted.

rough estimate of $1.7 \pm 0.1$ million new $\mathrm{HZ}$ cases can be expected each year in Europe.

Eleven publications from seven countries presented both overall and specific incidence rates by sex and/or by age group (See Additional file 1). In spite of the age groups, which differed from one study to another, agespecific $\mathrm{HZ}$ incidence rates appeared to hold steady during the review period at around 1/1 000 children $<10$ years, around 2/1 000 adults aged $<40$ years, around 1-4/1 000 adults aged $40-50$ years, and then increased rapidly after 50 years to around 7-8/1 000, up to $10 / 1000$ at 80 years of age and older (Figure 3). Figure 3 illustrates that in many countries in Europe, HZ incidence increases with age, and quite steeply so after 50 years of age. In all studies included in this review, incidence rates were consistently higher among women than men (male/female ratio range: 1.13-1.56), and this difference also increased with age.

Studies performed among immunocompetent people and among the general population (including both immunocompetent and immunocompromised people), showed that the risk of $\mathrm{HZ}$ was higher in the general population (9.80/1 000 in Germany and 4.31/1 000 in Italy) than among immunocompetent people (9.50/1 000 (Germany) and 4.07/1 000 (Italy)) [25,29].

\section{Discussion}

The present literature review of $\mathrm{HZ}$ incidence in Europe showed similar HZ incidence across the included countries for which data was available. Overall annual HZ incidence varied from 2.0-4.6/1 000 PY depending on the country, which is consistent with previous published estimates [43], and similar to those published in North America (1.25-3.7/1 000 PY [44,45]).

Our review confirms that $\mathrm{HZ}$ incidence increases sharply with age, from around 1/1 000 children $<10$ years up to 10/1 000 people over 80 years of age. These results are consistent with recent published estimates by Volpi et al. [43]. Annual $\mathrm{HZ}$ incidence in Europe has been reported as $0.3-0.74 / 1000$ children $<10$ years, $1.6 / 1000$ adults aged $<40$ years, $2.5 / 1000$ adults aged $20-50$ years, $7.8 / 1000$ adults aged 60 years or over, and 10/1 000 in elderly adults over 80 years of age [43].

As expected, the same increase in incidence rates with age was observed in the studies included in this review that reported age-specific incidence (Figure 3). The correlation between age and $\mathrm{HZ}$ incidence may be related to a decreased cellular-mediated immune response to VZV as result of immunosenescence $[44,46]$. It has been suggested that exposure to varicella reduces the risk of VZV reactivation by boosting specific immunity to the virus [38,47]. This hypothesis is supported by some studies which showed that repeated familial or occupational exposure is associated with a reduced risk of HZ [48-51], but others did not confirm this [46,52].

This review showed that incidence rates are systematically higher among women than men (male/female ratio around 1.4), and this difference increases with age, which has also been found in other studies [41,53]. Women over 


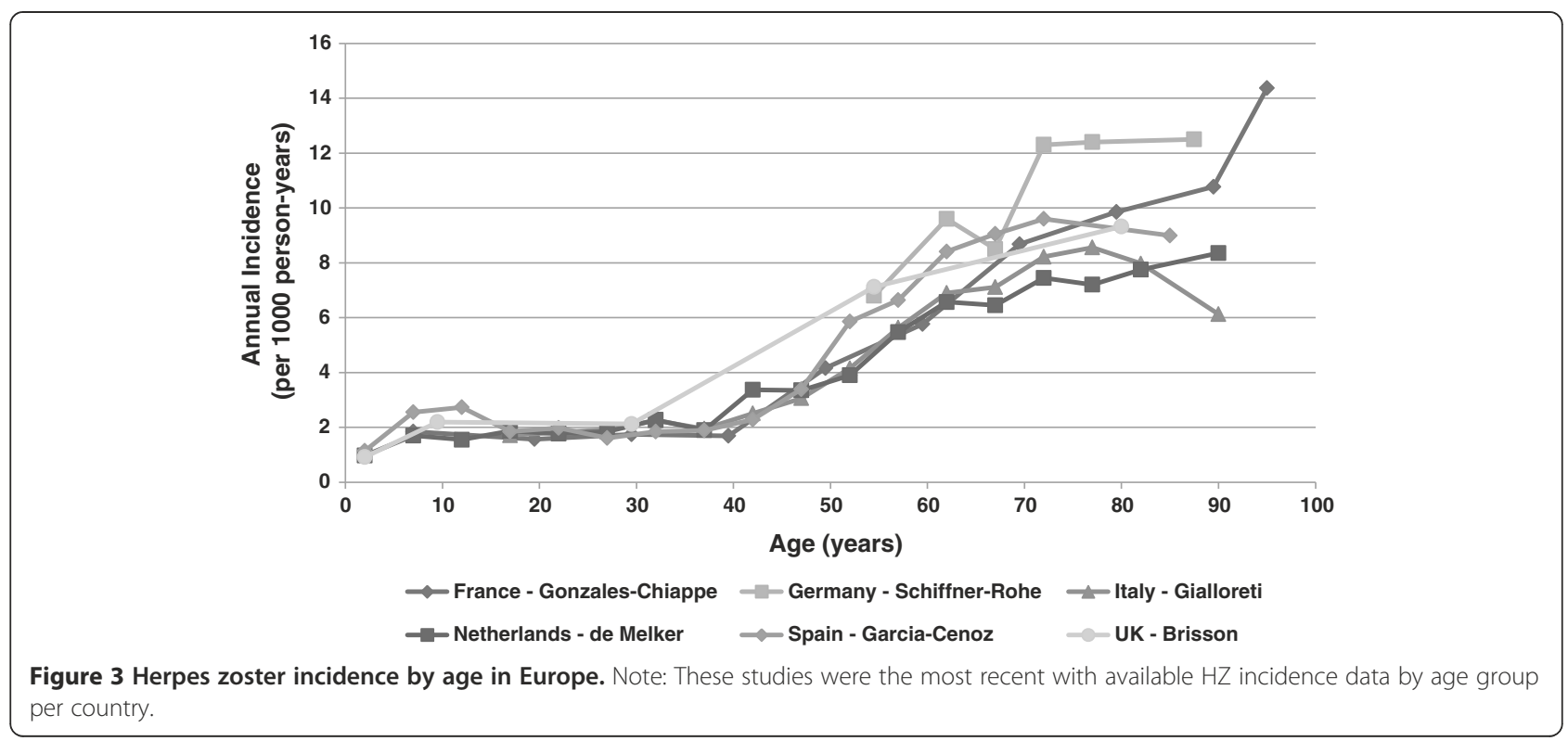

50 years of age seem to be particularly at risk. However, it is unclear whether the risk of $\mathrm{HZ}$ is increased in all women. Women might simply be more likely to seek medical advice, thereby causing a higher reporting rate, or there may be some biological mechanism by which women are more susceptible to VZV reactivation [54].

Our review excluded studies limited to immunocompromised populations, or individuals with primary or acquired immunodeficiency status. Nevertheless, as included studies were population-based, some of them made a distinction between the total study population and the immunocompetent population $[25,29]$. This review confirms that immunocompetent patients are at lower risk of developing $\mathrm{HZ}$ than the general population [25,29]. The control of VZV reactivation depends on the maintenance of adequate levels of cellular-mediated immunity to VZV, which explains why cellular-mediated immune deficiency is a risk factor for developing HZ [54].

In Europe, not all countries have some form of surveillance in place for HZ $[55,56]$ and there is marked heterogeneity in the type of $\mathrm{HZ}$ surveillance systems that do exist (national mandatory or sentinel), the type of data collected (case-based or aggregated) and the reported case classification (clinical and/or laboratory) [57]. Most surveillance systems operate using reports of clinical cases [57].

This review highlights the need to identify standardized surveillance methods in order to improve data comparability within European Union Member States and, in the framework of introducing $\mathrm{HZ}$ vaccination, to monitor the impact of immunization on the epidemiology of HZ.

Since most of the European studies in this review were performed and published in the last 10 years, it was difficult to look at a time trend variation in the risk of HZ. The only country (the UK) with two incidence rate estimates, which were about 30 years apart, provided two close figures: $3.40 / 1000$ people in 1975 vs. 3.73/1 000 people in 2000 [38,40]. However, this comparison is delicate since the first study was retrospective [38] and the second prospective [40].

In the literature, there are conflicting data with regard to whether age-adjusted HZ incidence is changing over time $[7,58]$. Indeed, the literature fails to show evidence of any change of $\mathrm{HZ}$ incidence over time, notably in relation to varicella vaccination. Longitudinal data, including a few years of baseline before possible routine use of the varicella vaccine in children or adolescents, and a sufficient number of years of data to detect a trend (at least 3 , preferably more) after the implementation of the vaccine will be needed to assess the impact of varicella vaccination on $\mathrm{HZ}$ incidence [59]. Such data are available from the US where varicella vaccination has been used routinely since 1995; however no clear conclusions were drawn on the impact on HZ incidence. Some authors did not observe any impact of varicella vaccination on $\mathrm{HZ}$ incidence $[7,58]$ and others observed an increase [60]. Moreover, looking at a potential HZ incidence trend overtime is challenging and depends on the availability of baseline data collected using comparable study methods in populations with comparable health care behavior. Comparing results across studies and time periods must take into account different study methods and must adjust for changes in the age structure of the population over time. As the proportion of older people grows in Europe [61], HZ is likely to become a more important public health issue in the future. The apparently increasing proportion of immunocompromised persons 
due to medical conditions or medication in the population, and the effect this may have on HZ, must also be considered.

This literature review has various limitations. First of all, this review included studies with different designs: direct prospective recruitment of patients with $\mathrm{HZ}$ in health care settings during a defined study period, and retrospective identification through medical files from a number of practitioners. In general, prospective recruitment methods are considered to be preferable, whereas retrospective recruitment poses some methodological problems regarding data quality and missing data. However, this was taken into account in the reading grid, which assigned a higher quality score to prospective studies than retrospective studies.

Moreover, in spite of their potential shortcomings, some studies based on large databases (UK, Italy, Spain, Germany) were included in this review. It is true that in the past the methods used in population-based studies, such as those used to extrapolate results obtained from a single database to the entire North American population, have been criticized [62]. Indeed, in this case the fact that the denominator used was the total number of persons registered in the national health care system and was presented as exhaustive raised a methodological problem linked to the calculation of the $\mathrm{HZ}$ incidence rate. This was questionable since no information was given on the number of persons who were not registered, compared to the national census. In that case, the denominator was a surrogate for the true number and the calculated rate could have been over-estimated. Recently, Yawn et al. showed that administrative data use alone appears to overestimate the number of $\mathrm{HZ}$ cases [53], and the potential coding error of HZ diagnosis in administrative data has also been investigated [63].

\section{Conclusions}

Available European epidemiological data on $\mathrm{HZ}$ have shortcomings which make accurate assessment of $\mathrm{HZ}$ incidence and change over time impossible. However, data are indicative that HZ incidence across Europe is comparable (about $3.4 \pm 0.2 / 1000$ when considering all age groups) and increases with age, especially after 50 years of age. This equates to a total of $1.7+/-0.1$ million new $\mathrm{HZ}$ cases each year in Europe.

\section{Complete list of countries}

Austria, Belgium, Bulgaria, Cyprus, Czech Republic, Denmark, Estonia, Finland, France, Germany, Greece, Hungary, Iceland, Ireland, Italy, Latvia, Lithuania, Luxembourg, Malta, the Netherlands, Norway, Poland, Portugal, Romania, Slovakia, Slovenia, Spain, Sweden, Switzerland, United Kingdom.

\section{Additional file}

Additional file 1: Incidence rates of herpes zoster (HZ) by age group
and by sex when available (/1 000) [20,22,23,25,29-32,34,35,37,39,40,64].

\section{Abbreviations}

HZ: Herpes zoster; PY: Person-years; UK: United Kingdom; VZV: Varicella-zoster virus.

\section{Competing interests}

This study was funded by SPMSD.

$\mathrm{SP}$ is an employee of Biostatem, Castries, France. She had specified relationships with Sanofi Pasteur MSD that might have an interest in the submitted work in the previous 6 years.

$\mathrm{HB}$ is an employee of SPMSD, Lyon, France.

AC declares that she has no competing interests.

$\mathrm{RJ}$ has received honoraria for consultancy, lectures and scientific meeting attendance from Sanofi Pasteur MSD, Merck Inc., Merck Frosst, Novartis and Astellas.

\section{Authors' contributions}

SP carried out the literature search, the selection of the articles, the scoring of the selected papers, and the extraction of the data and drafted the manuscript. HB performed the scoring of the selected papers, the extraction of the data and participated in drafting the manuscript. AC and RJ helped to interpret the results of the review and to draft the manuscript. All authors read and approved the final manuscript.

\section{Acknowledgements}

We would like to acknowledge Florence Baron-Papillon and Laurence Serradell-Vallejo (Sanofi Pasteur MSD, Lyon, France) for their contributions in reviewing the draft versions of this manuscript. The authors thank Ms Trudy Perdrix-Thoma for editorial assistance. SP received a funding from SPMSD to perform the literature search, the results analysis and the draft of the manuscript.

\section{Author details}

${ }^{1}$ Biostatem, Parc d'Activité Via Domitia, 205 Avenue des Gardians, 34160, Castries, France. ${ }^{2}$ Centro de Salud de Ayora, Avenida Argentina, 746620 Ayora, Valencia, Spain. ${ }^{3}$ Epidemiology Department, Sanofi Pasteur MSD, 8 rue Jonas Salk, 69007, Lyon, France. ${ }^{4}$ Department of Ophthalmology, University of Bristol, Bristol, UK.

Received: 29 October 2012 Accepted: 6 March 2013 Published: 10 April 2013

\section{References}

1. Thiry N, Beutels P, Shkedy Z, Vranckx R, Vandermeulen C, Van Der Wielen M, Van Damme P: The seroepidemiology of primary varicella-zoster virus infection in Flanders (Belgium). Eur J Pediatr 2002, 161:588-593.

2. British Society for the Study of Infection: Guidelines for the management of shingles: report of a working group of the British Society for the Study Infection. J Infect 1995, 30:193-200.

3. Gross G, Schöfer H, Wassilew SW, Friese K, Timm A, Guthoff R, Pau HW, Malin JP, Wutzler P, Doerr HW: Herpes zoster guideline of the German Dermatology Society (DDG). J Clin Virol 2003, 26:277-289.

4. Lee VK, Simpkins L: Herpes Zoster and Postherpetic Neuralgia in the Elderly. Geriatr Nurs 2000, 21:132-136.

5. Edmunds WJ, Brisson M, Rose JD: The epidemiology of herpes zoster and potential cost-effectiveness of vaccination in England and Wales. Vaccine 2001, 19:3076-3090.

6. Schmader K: Herpes Zoster in Older Adults. Clin Infect Dis 2001, 32:1481-1486.

7. Yawn BP, Saddier P, Wollan PC, Sauver JL, Kurland MJ, SY LS: A PopulationBased Study of the Incidence and Complication Rates of Herpes Zoster Before Zoster Vaccine Introduction. Mayo Clin Proc 2007, 82:1341-1349.

8. Sengupta N, Breuer J: A Global Perspective of the Epidemiology and Burden of Varicella-Zoster Virus. Curr Ped Rev 2009, 5:207-228.

9. Hannouche D, Alfandari S, Bouhour D, Fouchard N, Geffray L, Quinet B: Prise en charge des infections à VZV. Med Mal Infect 1998, 28:1-8. Article in French. 
10. Johnson RW, Wasner G, Saddier P, Baron R: Postherpetic neuralgia: epidemiology, pathophysiology and management. Expert Rev Neurother 2007, 7:1581-1595

11. Scott FT, Leedham-Green ME, Barrett-Muir WY, Hawrami K, Gallagher WJ, Johnson R, Breuer J: A Study of Shingles and the Development of Postherpetic Neuralgia in East London. J Medl Virol 2003, 70:S24-S30.

12. Scott FT, Johnson RW, Leedham-Green ME, Davies E, Edmunds WJ, Breuer J: The burden of Herpes Zoster: A prospective population based study. Vaccine 2006, 24:1308-1314.

13. Moher D, Liberati A, Tetzlaff J, Altman DG: Reprint-preferred reporting items for systematic reviews and meta-analyses: the PRISMA statement. Phys Ther 2009, 89:873-880.

14. Meister W, Neiss A, Gross G, Doerr HW, Höbel W, Malin JP, Von Essen J, Reimann BY, Witke C, Wutzler P: Demography, Symptomatology, and Course of Disease in Ambulatory Zoster Patients. Intervirol 1998, 41:272-277.

15. Chidiac $C$, Bruxelle J, Daurès J-P, Hoang-Xuan $T$, Morel $P$, Leplège $A, E$ Hasnaoui A, De Labaryere C: Characteristics of Patients with Herpes Zoster on Presentation to Practitioners in France. Clin Infect Dis 2001 33:62-69.

16. di Luzio PU, Arpinelli F, Visonà G: Herpes Zoster and its Complications in Italy: An Observational Survey. J Infect 1999, 38:116-120.

17. Gabutti G, Serenelli C, Sarno O, Marconi S, Corazza M, Virgili A: Epidemiologic features of patients affected by herpes zoster: database analysis of the Ferrara University Dermatology Unit, Italy. Méd Maladies Infect 2010, 40:268-272.

18. Parlato A, Spica VR, Ciccozzi M, Farchi F, Gallè F, Di Onofrio V, Franco E, Liguori G: Compliance with herpes zoster vaccination in young and adult individuals in two regions of Italy. BMC Public Health 2010, 10:1-5.

19. Pérez-Faérinos N, Ordobas M, Garcia-Fernandez C, Garcia-Comas L, Canellas S, Rodero I, Gutiérrez-Rodriguez A, Garcia-Gutiérrez J, Ramirez R: Varicella and Herpes Zoster in Madrid, based on the Sentinel General Practitioner Network: 1997-2004. BMC Infect Dis 2007, 7:1-5.

20. Truyers C, Bartholomeeusen S, Buntinx F, De Loof J: Incidentie van herpes zoster. Huisarts Onderzoek 2005, 34:260-262. Article in Flemish.

21. Réseau Sentinelles Coordination nationale: Bilan annuel du réseau Sentinelles Janvier-Décembre 2009. Rapport d'activité. Paris:; 2009.

22. Gonzalez Chiappe S, Sarazin M, Turbelin C, Lasserre A, Pelat C, Bonmarin I, Chosidow O, Blanchon T, Hanslik T: Herpes zoster: Burden of disease in France. Vaccine 2010, 28:7933-7938.

23. Mick G, Gallais JL, Simon F, Pinchinat S, Bloch K, Beillat M, Serradell L, Derrough T: Burden of Herpes Zoster and postherpetic neuralgia: incidence, proportion, and associated costs in the French population aged 50 or over. Rev Epidemio/ Sante Publique 2010, 58:393-401. Article in French.

24. Czernichow S, Dupuy A, Flahault A, Chosidow O: Zona: enquête d'incidence chez les médecins généralistes du réseau "Sentinelles". Ann Dermatol Venereol 2001, 128:497-501. Article in French.

25. Schiffner-Rohe VJ, Jow S, Lilie HM, Köster I, Schubert I: Herpes Zoster in Germany. A retrospective analyse of SHL data. MMW Fortschr Med 2010, 151(4):193-197. Article in German.

26. Paul E, Thiel T: Epidemiology of varicella zoster infection. Results of a prospective study in the Ansbach area. Hautarzt 1996, 47:604-609. Article in German.

27. Helgason S, Sigurdsson JA, Gudmundsson S: The Clinical Course of Herpes Zoster: a Prospective Study in Primary Care. Eur J Gen Pract 1996, 2:12-16.

28. Petursson G, Helgason S, Gudmundsson S, Sigurdsson JA: Herpes zoster in children and adolescents. Pediatr Infect Dis J 1998, 17:905-908.

29. Emberti Gialloreti L, Merito M, Pezzotti P, Naldi L, Gatti A, Beillat M, Serradell L, Di Marzo R, Volpi A: Epidemiology and economic burden of herpes zoster and post-herpetic neuralgia in Italy: A retrospective, populationbased study. BMC Infect Dis 2010, 10:1-11

30. Di Legami V, Gianino MM, Ciofi Degli Atti M, Massari M, Migliardi A, Scalia Tomba G, Zotti C: Epidemiology and costs of herpes zoster: Background data to estimate the impact of vaccination. Vaccine 2007, 25:7598-7604.

31. Opstelten W, Van Essen GA, Schellevis FG, Verheij TJM, Moons KGM: Gender as an Independent Risk Factor for Herpes Zoster: A Population-Based Prospective Study. Ann Epidemiol 2006, 16:692-695.

32. de Melker $H$, Berbers $G$, Hahné $S$, Rümke $H$, van den Hof $S$, de Wit A, Boot $H$ : The epidemiology of varicella and herpes zoster in The Netherlands: implications for varicella zoster virus vaccination. Vaccine 2006, 24:3946-3952.
33. Opstelten W, Mauritz JW, De Wit NJ, Van Wijck AJM, Stalman WAB, Van Essen GA: Herpes zoster and postherpetic neuralgia: incidence and risk indicators using a general practice research database. Fam Pract 2002, 19:471-475.

34. Cebrian-Cuenca AM, Diez-Domingo J, Puig-Barbera J, Navarro-Perez J, Sanmartin-Rodriguez M: Epidemiology of Herpes Zoster Infection among Patients Treated in Primary Care Centres in the Valencian Community (Spain). BMC Fam Pract 2010, 11:1-23.

35. Garcia Cenoz M, Castilla J, Montes Y, Moran J, Salaberri A, Elia F, Floristan Y, Rodrigo I, Irisarri F, Arriazu M, Zabala A, Barricarte A: Varicella and herpes zoster incidence prior to the introduction of systematic child vaccination in Navarre, 2005-2006. An Sist Sanit Navar 2011, 30:71-80.

36. Richard J-L, Zimmermann H: Herpès zoster 1998 - 2001. SentinellaJahresbericht; 2001. 6. Article in French.

37. Gauthier A, Breuer J, Carrington D, Martin M, Rémy V: Epidemiology and cost of herpes zoster and post-herpetic neuralgia in the United Kingdom. Epidemiol Infect 2009, 137:38-47.

38. Hope-Simpson RE: The Nature of Herpes Zoster: A Long-term Study and a New Hypothesis. Proc $R$ Soc Med 1965, 58:9-20.

39. Fleming DM, Cross KW, Cobb WA, Chapman RS: Gender difference in the incidence of shingles. Epidemiol Infect 2003, 132:1-5.

40. Brisson M, Edmunds WJ: Epidemiology of Varicella-Zoster Virus in England and Wales. J Med Virol 2003, 70:59-S14.

41. Glynn C, Crockford G, Gavaghan D, Cardno P, Price D, Miller J: Epidemiology of shingles. J Roy Soc Med 1990, 83:617-619.

42. Eurostat: Population at 1 January.. http://epp.eurostat.ec.europa.eu/.

43. Volpi A, Gross G, Hercogova J, Johnson RW: Current Management of Herpes Zoster: The European View. Am J Clin Dermatol 2005, 6:317-325.

44. Donahue JG, Choo PW, Manson JE, Platt R: The Incidence of Herpes Zoster. Arch Intern Med 1995, 155:1605-1609.

45. Ragozzino MW, Melton LJ III, Kurland LT, Chu CP, Perry HO: Populationbased study of herpes zoster and its sequelae. Medicine 1982, 61:310-316.

46. Gaillat J, Gajdos V, Launay O, Malvy D, Demoures B, Lewden L, Pinchinat S, Derrough T, Sana C, Caulin E, Soubeyrand B: Does monastic life predispose to the risk of Saint Anthony's fire (herpes zoster)? Clin Infect Dis 2011, 53:405-410.

47. Floret D: Immunisation against varicella. Therapie 2005, 60:275-282.

48. Terada K, Yoshihiro K, Kawano S, Morita T: Incidence of herpes zoster in pediatricians and family practitioners. Estimation of efficacy of varicella vaccine for protection against herpes zoster in the elderly. Kawasaki Med J 1994, 20:99-102

49. Brisson M, Gay NJ, Edmunds WJ, Andrews NJ: Exposure to varicella boosts immunity to herpes-zoster: implications for mass vaccination against chickenpox. Vaccine 2002, 20:2500-2507.

50. Thomas SL, Wheeler JG, Hall AJ: Contacts with varicella or with children and protection against herpers zoster in adults:a case-control study. Lancet 2002, 360:678-682.

51. Salleras M, Dominguez A, Soldevila N, Prat A, Garrido P, Torner N, Borras E, Salleras L: Contacts with children and young people and adult risk of suffering herpes zoster. Vaccine 2011, 29:7602-7605.

52. Garnett GP, Grenfell BT: The epidemiology of varicella-zoster virus infections: the influence of varicella on the prevalence of herpes zoster Epidemiol Infect 1992, 108:513-528.

53. Yawn BP, Wollan P, St Sauver J: Comparing shingles incidence and complication rates from medical record review and administrative database estimates: how close are they? Am J Epidemio/ 2011, 174:1054-1061.

54. Thomas SL, Hall AJ: What does epidemiology tell us about risk factors for herpes zoster? Lancet Infect Dis 2004, 1:26-33.

55. Pinot de Moira A, Nardone A: Varicella zoster virus vaccination policies and surveillance strategies in Europe. Euro Surveill 2005, 10:43-45.

56. Report Venice II: Varicella and herpes Zoster surveillance and vaccination recommandations 2010-11. Stockholm: ECDC; 2010

57. Report Statens Serum Institut: Surveillance of Varicella and Herpes Zoster in Europe. Copenhagen:; 2010.

58. Jumaan AO, Yu O, Jackson LA, Bohlke K, Galil K, Seward JF: Incidence of herpes-zoster, before and after varicella vaccination associated decreases in the incidence of varicella, 1992-2002. J Infect Dis 2005, 191:2002-2007.

59. Alain S, Paccalin M, Larnaudie S, Perreaux F, Launay O: Impact of routine pediatric varicella vaccination on the epidemiology of herpes zoster. Med Mal Infect 2009, 39:698-706. Article in French. 
60. Yih WK, Brooks DR, Lett SM, Jumaan AO, Zhang Z, Clements KM, Seward JF: The incidence of varicella and herpes zoster in Massachusetts as measured by the Behavioral Risk Factor Surveillance System (BRFSS) during a period of increasing varicella vaccine coverage, 1998-2003. BMC Public Health 2005, 5(68):1-9.

61. Eurostat: Active ageing and solidarity between generations. A statistical portrait of the European Union 2012. 2012th edition. Luxembourg: Luxembourg; 2012.

62. Jumaan A, Schmid DS, Gargiullo P, Seward J: Letter to the Editor. Vaccine 2004, 22:3228-3231.

63. Joesoef MR: Potential coding error of herpes zoster $(\mathrm{HZ})$ vaccination and HZ diagnosis in administrative data. Vaccine 2011, 29:2008-2009.

64. Brisson M, Edmunds WJ, Law B, Gay NJ, Wall R, Brownell M, Roos L, De Serres G: Epidemiology of varicella zoster virus infection in Canada and the United Kingdom. Epidemiol Infect 2001, 127:305-314.

doi:10.1186/1471-2334-13-170

Cite this article as: Pinchinat et al:: Similar herpes zoster incidence

across Europe: results from a systematic literature review. BMC Infectious Diseases 2013 13:170.

\section{Submit your next manuscript to BioMed Central and take full advantage of:}

- Convenient online submission

- Thorough peer review

- No space constraints or color figure charges

- Immediate publication on acceptance

- Inclusion in PubMed, CAS, Scopus and Google Scholar

- Research which is freely available for redistribution 